\title{
Occurrence of Botrytis cinerea and Subsequent Disease Expression at Different Positions on Leaves and Bunches of Grape
}

\author{
Gustav Holz, Minique Gütschow, and Sonja Coertze, Department of Plant Pathology, University of Stellenbosch, \\ Private Bag X1, Matieland 7602 (Stellenbosch), South Africa; and Frikkie J. Calitz, ARC-Biometry Unit, Private \\ Bag X5013, Stellenbosch 7599, South Africa
}

\begin{abstract}
Holz, G., Gütschow, M., Coertze, S., and Calitz, F. J. 2003. Occurrence of Botrytis cinerea and subsequent disease expression at different positions on leaves and bunches of grape. Plant Dis. 87:351-358.

The occurrence of Botrytis cinerea and subsequent disease expression at different positions on leaves and bunches of grape was determined from 1996 to 2000. Different techniques were used to detect viable inoculum on material obtained from table (cvs. Barlinka and Dauphine) and wine grape (cv. Merlot) vineyards. Isolations were made from berry skins on Kerssies' B. cinerea selective medium or on water agar medium supplemented with paraquat. Leaves and parts of bunches bearing three to seven berries on a short rachis section were used untreated or treated with paraquat, or were frozen for $1 \mathrm{~h}$ at $-12^{\circ} \mathrm{C}$. Paraquat and freezing were used to terminate host resistance and to promote the development of the pathogen from the tissues. The material was used untreated to detect the pathogen on the surface, or were surface-sterilized to detect mycelia (latent infection) in the tissue. B. cinerea occurred in a consistent pattern in leaves and bunches in all vineyards. Based on the combined data for tissues exposed and unexposed to paraquat, $B$. cinerea occurred predominantly in bunches and was mostly associated with the bases of the berry and the pedicel. Overall, approximately $30 \%$ of the berries yielded $B$. cinerea at these positions. The next prominent positions occupied were leaf blades, rachises, and laterals, of which approximately $20 \%$ yielded $B$. cinerea. The pathogen occupied the petioles less often $(10 \%)$, and the berry cheek infrequently $(5 \%)$. The stylar end of the berries, on the other hand, was virtually free $(0.02 \%)$ of the pathogen. Disease expression in bunches displayed the pattern showed by the inoculum ecology, and symptoms consistently developed first at the berry-pedicel attachment zone. The isolation studies showed that the pathogen seldom occurred on the surface or in the skin tissue near the base, cheek, or stylar end of berries. Latent infections in the berry base were also few at véraison and harvest. Collectively, the findings indicate that conidia dispersed in early season in bunches, and residing superficially at the berry-pedicel attachment zone, are a major factor in B. cinerea bunch rot.
\end{abstract}

Additional keywords: infection pathway, inoculum ecology, latent infection, surface inoculum

Botrytis cinerea infects leaves, buds, canes, and bunches of grape (Vitis vinifera) and causes gray mold (45). Leaves are not normally considered susceptible, but infection during periods of prolonged wetness can cause leaf spots that produce conidia $(45,64)$. Mycelia growing from the peduncle sometimes invades the nodes of shoots and occasionally colonizes the winter buds, ultimately killing these organs (1). Rachises undergo little risk from direct infection by $B$. cinerea conidia, but can occasionally be invaded by mycelia grow-

Corresponding author: G. Holz

E-mail: gh@sun.ac.za

This work was supported by grants from Deciduous Fruit Producer's Trust and the National Research Foundation.

Accepted for publication 17 October 2002.

Publication no. D-2003-0127-03R

(C) 2003 The American Phytopathological Society ing from flower debris or attached berries (24). Berries, on which the most prominent symptom is found (45), are considered resistant to infection when immature, and susceptible when mature $(25,45,49)$.

Different infection pathways have been described for $B$. cinerea on grape berries, namely through stigmata $(41,47)$, pedicels (27-29,42,54), natural openings (56), wounds (44), or by direct penetration of the cuticle $(10,12,49)$. Inoculation of immature berries often is followed by a latent period $(41,47)$. Evidence for the importance of these latent infections in subsequent disease development, and of the pathway used, is primarily circumstantial. Some workers $(41,47,60)$ found that berry infection takes place during bloom. They showed that $B$. cinerea invades the stigma and then becomes latent in necrotic style tissue at the stylar end of the berry. Grape clusters remain symptomless between the flowering period and the beginning of ripening, and a pathogenic relationship generally is established once the fruit rip- ens $(41,47)$. Pezet and Pont (54) found no evidence for the stylar end infection pathway and showed that latent infection was predominantly associated with the berry base. Their histological studies of laboratory-inoculated bunches showed that $B$. cinerea colonizes the stamens during bloom and invades their base situated on the receptacle. From there, it spreads into the berry base. Savage and Sall (57) were unable to detect the pathogen in immature berries. Studies with dry, airborne $B$. cinerea conidia showed that the skins of fresh, ripe berries (10) and berries at other growth stages $(11,12)$ provide an effective barrier to penetration. Consequently, few infections in grape berry skins were established by airborne conidia. According to Coertze and coworkers (10-12), these infections should not contribute to a gradual build-up of secondary inoculum in the vineyard, or to $B$. cinerea epiphytotics. Other workers $(15,52)$ also have questioned the contribution of latent infection in $B$. cinerea epiphytotics.

Difficulties in demonstrating the relative importance of the infection pathways on berries, and of latent $B$. cinerea infection in subsequent disease development, can partially be ascribed to a poor understanding of the ecology of the pathogen's inocula in grape bunches. Conidia of $B$. cinerea, a facultative saprophyte, are almost always present in vineyards $(7,13)$ and are deposited primarily from airborne inoculum or in water $(31,32)$ on leaves, buds, canes, and in bunches. Conidia of $B$. cinerea attach in two distinct stages to hydrophobic surfaces $(16,17)$. Immediate adhesion occurs upon hydration of freshly deposited conidia, whereas stronger adhesion occurs as conidia start to germinate. On grape berries, conidia of $B$. cinerea adhere more strongly when applied in water suspension or to the wet surface of grapes than when dry conidia are applied to a dry surface (61). Furthermore, conidia or germlings adhering to the cuticle are not easily dislodged from grape berry surfaces (61). Studies with dry, airborne $B$. cinerea conidia indicated that the pathogen did not survive for extended periods on the surface of moist or wet berries $(11,12)$. Therefore, in the event of wounding, a combination of fresh wounds, freshly dispersed conidia, and free water on the berry surface is necessary for successful wound infection (11). 
Little is known about the relation between conidial density, infection, and subsequent $B$. cinerea symptom expression on grape. Data on washings made from grape berries in Californian (18) and South African vineyards (G. Holz, unpublished data) indicated that the amount of $B$. cinerea on berry surfaces was very low throughout the season, and $B$. cinerea occurred as single CFU. In most studies where grape berries were artificially inoculated, suspensions containing $\geq 10^{4}$ conidia/ml were used as a standard procedure to induce symptom expression $\quad(2,6,9,15,38-40,44,46,48,65)$. Warren et al. (69) showed that suspensions containing $\geq 10^{4}$ conidia/ml were required on on-vine inflorescences and bunches of the highly susceptible wine grape cultivar, Chardonnay, to induce symptom expression on frozen inflorescences or berries. Hill et al. (25) calculated that, from a total of 3,500 conidia per $15.9-\mathrm{mm}^{2}$ cuticle surface, only 1 to 2 conidia were able to penetrate the isolated cuticle layer. These findings, and the data of Holz and coworkers $(10-12,22,26-29)$ on the infectivity of single, airborne $B$. cinerea conidia, suggest that disease expression by $B$. cinerea on grape is not dependent upon inoculum density. Furthermore, B. cinerea infection and disease expression is not exclusive to the grape berry cheek or pistil $(21,26-$ $29,42,54)$. Symptomatic leaves and colonized senescent floral debris and aborted berries retained in developing fruit clusters can contribute to the inoculum load occurring in the bunch, especially early in the season $(19,34,50,70)$. The importance of $B$. cinerea occurring at the berry base (26$29,42,54$ ), and probably at other positions, therefore may be underestimated in the epidemiology of B. cinerea and the development of epiphytotics in grapevine. Thus, knowledge of the ecology of $B$. cinerea on leaves and in bunches, latency, and the relationship between the incidence of $B$. cinerea and disease expression at various positions on leaves and in bunches is needed to plan effective disease control strategies; for example, in devising disease prediction models, timing fungicide application, biological control, and resistance breeding. The aims of this study were to (i) determine the occurrence of $B$. cinerea at different positions on grape berries and verify latent infection, and (ii) determine the relationship between the occurrence of $B$. cinerea and subsequent disease expression at different position on leaves and bunches. Preliminary reports of some aspects of this study have been published (22,26-29).

\section{MATERIALS AND METHODS}

Vineyards and grape material. Material was obtained from 1996 to 2000 from table grape vineyards (cvs. Dauphine and Barlinka) in De Doorns and Paarl, and wine grape vineyards (cv. Merlot) at Stellenbosch, Western Cape province, South
Africa. The De Doorns and Paarl regions are approximately $120 \mathrm{~km}$ apart and separated by a series of mountain ranges. The Stellenbosch region is adjacent to that of Paarl. The regions have a moderate Mediterranean climate. De Doorns is marginally drier than Paarl, and Stellenbosch is marginally wetter than Paarl. Table grape vineyard blocks ranged from 1 to 5 ha and the vines were trained to a slanting trellis at 3-by-1.5-m spacings. Canopy management and bunch preparation were done according to the guidelines of Van der Merwe et al. (67). Wine grape vineyard blocks ranged from 1 to 5 ha and the vines were trained to a two-wire trellis system or goblet vines. All vines were trickle irrigated. In most of the vineyards, a recommended program (14) for the control of downy mildew, powdery mildew, and $B$. cinerea was generally followed. Sprays against downy mildew started at 10- to 15$\mathrm{cm}$ shoot length and were applied until pea size. Fungicides used were folpet (Folpan $50 \mathrm{WP}$, Agrihold, Silverton, South Africa), fosetyl-Al/mancozeb (Mikal M 44/26 WP, Rhône-Poulenc Agrichem SA, Onderstepoort, South Africa), mancozeb (Dithane M45 80 WP, FBC Holdings, Chloorkop, South Africa), and mancozeb/oxadixyl (Recoil 56/8 WP, Bayer SA, Isando, South Africa). Applications against powdery mildew started at 2- to 5-cm shoot length and were applied until 3 weeks before harvest. Fungicides used were penconazole (Topaz 10 EC, Syngenta SA, Halfway House, South Africa), pyrifenox (Dorado 48 EC, Ciba-Geigy (Pty) Ltd., Isando, South Africa), and triadimenol (Bayfidan 25 EC, Bayer). Sprays against $B$. cinerea were applied at flowering, bunch closure, véraison, and 2 weeks before harvest. Fungicides used were iprodione (Rovral Flo 25 EC, Aventis CropScience SA, Centurion, South Africa) and pyrimethanil (Scala 40 EC, Aventis). Shoots with sound, unblemished bunches, each from a different arbitrarily chosen vine, were obtained at pea size, bunch closure (approximately $6^{\circ} \mathrm{Brix}$ ), véraison (approximately $11^{\circ}$ Brix), and the harvest stage (approximately $16^{\circ}$ Brix) for the different investigations. Material was collected 1 to 3 days before fungicide applications against $B$. cinerea were made.

Detection of $B$. cinerea on berries and verification of latent infection. The occurrence of $B$. cinerea at different positions on berries was investigated on Barlinka grape obtained from 1996 to 2000 from two vineyards in De Doorns and Paarl. Three techniques were used to determine viable inoculum occurring on the skin surface and latent mycelia occurring in the skin tissue. For the first technique, isolations were made from berry skins at bunch closure, véraison, and the harvest stage. Two berries were arbitrarily cut at the pedicel from each of 100 bunches per vineyard. The berries from each vineyard were divided into two groups of 100 berries each. Berries of one group were left untreated, and those of the other group were surface sterilized $(30 \mathrm{~s}$ in $70 \%$ ethanol, 2 min in $0.35 \%$ sodium hypochlorite, $30 \mathrm{~s}$ in $70 \%$ ethanol) and air dried. Three epidermal tissue segments (approximately 5 by $7 \mathrm{~mm}$ ), one from near the base, one from the cheek, and another from near the stylar end, were cut from each berry, placed with the cuticle upward on Kerssies' $B$. cinerea selective medium (35) or on water agar medium supplemented with paraquat (20) (WPK Paraquat, 200 g/liter [bipyridyl]; WPK Agricultural, Cape Town, South Africa), and incubated at $22^{\circ} \mathrm{C}$.

For the second technique, parts of bunches were treated with paraquat at peasize, bunch closure, véraison, and harvest stage and incubated at high relative humidity. The bunches were cut into sections bearing three to seven berries on a short rachis. The sections were divided in two groups; one group was not treated, whereas the other group was surface sterilized as described previously and air dried. Both groups of sections were immersed in paraquat solution ( $30 \mathrm{ml} /$ liter of water) for $30 \mathrm{~s}$, rinsed in sterile deionized water, and air dried. The sections were placed on sterile epoxy-coated steel mesh screens (53 by 28 by $2 \mathrm{~cm}$ ) and placed in ethanol-disinfected perspex (Cape Plastics, Cape Town, South Africa) chambers (60 by 30 by $60 \mathrm{~cm}$ ) lined with a sheet of chromatography paper with the base resting in deionized water to establish high $(\geq 93 \%)$ relative humidity (RH). The screens were kept in the chambers for $24 \mathrm{~h}$ at $22^{\circ} \mathrm{C}$ with a 12 $\mathrm{h}$ photoperiod to promote the development of $B$. cinerea, then transferred to identical, dry perspex chambers $(\leq 56 \% \mathrm{RH})$ for 10 days, followed by a 4-day incubation at high $\mathrm{RH}$ to promote symptom expression and sporulation by the pathogen $(10,12)$. The experimental layout was a four-by-two factorial design with two block replications (vineyards at two locations) repeated for three seasons (1996-97, 1997-98, and 1998-99). The factors were the four growth stages (pea-size, bunch closure, véraison, and harvest) and two treatments (untreated and surface-sterilized berries). An experimental unit consisted of 125 sections bearing approximately 500 berries.

For the third technique, paraquat and freezing were compared as methods for detecting viable mycelia in berries at the different growth stages. The bunches were cut into sections and the sections were surface sterilized as described previously. The sections were divided into two groups. One group was immersed in paraquat solution, rinsed in sterile, deionized water, air dried, and incubated on steel mesh screens in moist chambers as described before. The other group was rinsed in sterile, deionized water, air dried, placed on steel mesh 
screens, and kept for $1 \mathrm{~h}$ at $-12^{\circ} \mathrm{C}$ in an industrial freezer. After removal from the freezer, the screens were kept in dry ethanol-disinfected perspex chambers $(\leq 56 \%$ $\mathrm{RH}$ ) for 10 days at $22^{\circ} \mathrm{C}$, followed by a 4 day incubation period at high RH to promote symptom expression and sporulation. The experimental layout was a four-by-two factorial design with two block replications (vineyards at two locations) and repeated for two seasons (1998-99 and 1999-2000). The factors were the four growth stages (pea-size, bunch closure, véraison, and harvest) and two treatments (freezing and paraquat). An experimental unit consisted of 216 sections bearing approximately 900 berries.

The treatments provided conditions that discriminate between conidial germination and the development of germlings on the berry surface, and the development of latent mycelia in the berry skin during the incubation period. Both the paraquat $(3,8,20,55)$ and the freezing $(10,12,29)$ treatments terminated host resistance in the cells of the cuticular membrane without damaging host tissue and, thus, facilitated the development of both surface conidia and latent mycelia in the skin tissue. Previous microscopic observations of berry skins on Kerssies' medium $(10,12)$ and paraquat medium $(21,29)$ showed that no superficial mycelial growth developed on the skin segments during the first 5 days of incubation. Hyphal growth usually occurred from cells underlying the cuticle into the medium after 5 days, which indicated direct penetration by surface conidia, or the development of latent mycelia from skin tissue during the incubation period. Surface sterilization eliminated $B$. cinerea from the berry surface and facilitated the detection of mycelia in the skin tissue $(10,12,21)$. Therefore, according to these differential criteria, the development of $B$. cinerea from skin segments obtained from unsterile berries, and from unsterile, paraquat-treated or frozen berries, resulted from the development of both surface conidia and latent mycelia. On skin segments obtained from surface-sterilized berries, surface-sterilized berries exposed to paraquat, or frozen berries, the pathogen developed from latent mycelia in the skin tissue only. The berries were examined daily for symptom development, and the presence of $B$. cinerea was positively identified by lesion development and the formation of sporulating colonies of the pathogen at the base, cheek, and stylar end (Fig. 1). In the case of isolation studies, the three positions were represented by skin segments removed from the three positions. The presence of $B$. cinerea at each site was recorded for each sample, and the incidence of berries yielding the pathogen at a specific position was calculated for each sterilization regime. For experiments with bunch sections, the $B$. cinerea incidence data were transformed to logits prior to analysis. Levene's test for homogeneity of variance was performed to test the seasonal variability in observations of comparable magnitude. Combined analysis of variance (ANOVA) was performed using SAS (version 8.2; Statistical Analysis System, Cary, NC). The ShapiroWilk test was performed to test for nonnormality (58). Student's $t$ least significant difference (LSD) was calculated at the 5\% confidence level to compare treatment means (59).

Detection of $B$. cinerea and subsequent disease expression at different positions on leaves and bunches. The studies were conducted with material obtained from 1999 to 2000 from five Dauphine vineyards at De Doorns and five Merlot vineyards at Stellenbosch. Leaves (20 per vineyard, 100 per cultivar) and bunches (10 per vineyard, 50 per cultivar) were obtained at pea-size, bunch closure, and 2 weeks prior to harvest. At each sampling, leaves and bunches from each vineyard were divided into two equal groups. The bunches in each group were cut into sections bearing three to seven berries on a short rachis section. Material of one group was rinsed in sterile, deionized water and air dried. The material of the other group was immersed in paraquat, rinsed in sterile, deionized water, and air dried as described previously. The treatments provided conditions that discriminated between symptom expression by inocula (surface conidia and latent mycelia) on tissues with host resistance operative (control treatment), or terminated (paraquat treatment). Each leaf or bunch section was sealed in a polythene bag. The bags were lined with wet paper towels to establish high $\mathrm{RH}$ necessary for the development of $B$. cinerea and subsequent symptom expression and kept at $22^{\circ} \mathrm{C}$ under a diurnal light regime (12-h photoperiod). The material was examined daily for symptom development, and the presence of $B$. cinerea was positively identified by lesion development and the formation of sporulating colonies of $B$. cinerea at the different positions. In the case of leaves, positions were the blades and petioles. Positions in the bunches (Fig. 1) were rachises, laterals, pedicels, and the base, cheek, and stylar end of berries. The presence of B. cinerea at each position was recorded, and the incidence calculated for each treatment. A split-plot experimental design was used in all experiments. Statistical computations were performed using SAS. The experiments were subjected to analyses of normality of residuals $(P>0.05=$ normality $)$ using the Shapiro and Wilk test for normality (58). The data was examined further by using ANOVA and the treatment means were compared using Student's $t$ LSD $(P=0.05)$ (59). Using data recorded for both seasons from the different vineyards of each cultivar, correlation coefficients were computed to explore the degree of closeness of linear relationships between $B$. cinerea incidences recorded in material with host resistance operative and host resistance terminated.

\section{RESULTS}

Detection of $B$. cinerea on berries and verification of latent infection. At each growth stage of each season, $B$. cinerea developed sporadically from a few of the skin segments removed from berries obtained from the two vineyards. These seg-

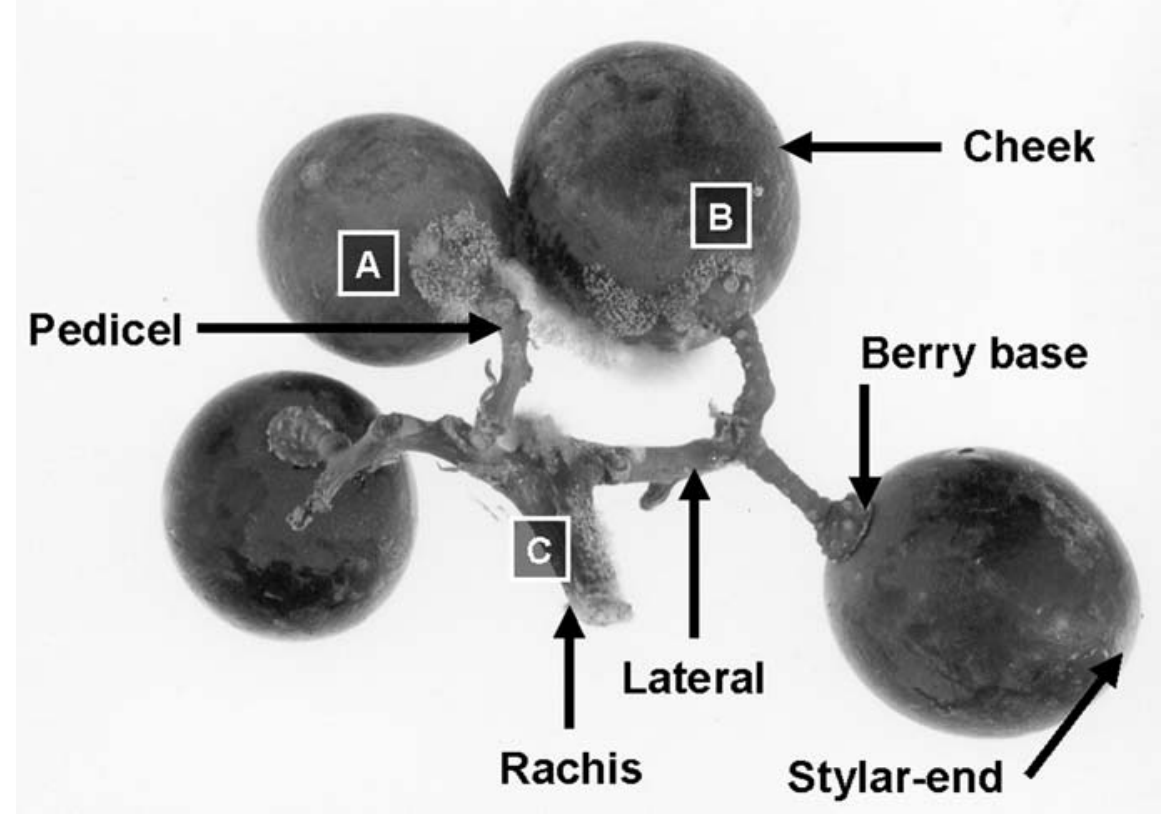

Fig. 1. Positions in grape bunches monitored for the occurrence of Botrytis cinerea. The pathogen developed from $\mathbf{A}$, the base of the pedicel, $\mathbf{B}$, the berry, and $\mathbf{C}$, the rachis of this table grape (cv. Barlinka) bunch section, which was treated with paraquat at the ripe stage. 
ments were not confined to a specific site on the berry and were found erratically at each sampling at the three berry positions. Therefore, the data were not analyzed. Segments with $B$. cinerea originated mostly from unsterile berries and seldom from surface-sterilized berries. Overall, 0.76 and $0.02 \%$ of skin segments removed from unsterile and sterile berries, respectively, yielded the pathogen. Furthermore, the pathogen never developed from more than one site per berry. Therefore, of the 4,800 berries from which skins were isolated, B. cinerea developed from $2.3 \%$ of unsterile and $0.06 \%$ of sterile berries.

The pathogen developed in a consistent pattern from the different positions on berries on bunch sections used in both the paraquat and the paraquat compared with freezing experiments. At all samplings, the stylar end remained mostly asymptomatic and virtually free from $B$. cinerea. Overall,

Table 1. Analysis of variance of the incidence of Botrytis cinerea (logit transformed) recorded in the paraquat experiment at the base and cheek of Barlinka grape berries obtained during 1996-97, 199798, and 1998-99 from vineyards at De Doorns and Paarl

\begin{tabular}{|c|c|c|c|c|c|}
\hline \multirow[b]{2}{*}{ Source } & \multirow[b]{2}{*}{ df } & \multicolumn{2}{|c|}{ Base } & \multicolumn{2}{|c|}{ Cheek } \\
\hline & & MS & $P>F$ & MS & $P>F$ \\
\hline Location & 1 & 0.6915 & 0.3393 & 0.0403 & 0.8026 \\
\hline Season $(\mathrm{S})$ & 2 & 0.2071 & 0.7544 & 0.9559 & 0.2408 \\
\hline Growth stage (G) & 3 & 20.3068 & $<0.0001$ & 2.3358 & 0.0261 \\
\hline $\mathrm{S} \times \mathrm{G}$ & 6 & 0.4440 & 0.7187 & 0.4608 & 0.6297 \\
\hline Treatment $(T)^{y}$ & 1 & 13.2454 & 0.0003 & 2.8228 & 0.0454 \\
\hline $\mathrm{S} \times \mathrm{T}$ & 2 & 1.1650 & 0.2227 & 1.0938 & 0.1988 \\
\hline $\mathrm{G} \times \mathrm{T}$ & 3 & 0.2284 & 0.8147 & 0.6871 & 0.3733 \\
\hline $\mathrm{S} \times \mathrm{G} \times \mathrm{T}$ & 6 & 0.5229 & 0.6376 & 0.5957 & 0.4830 \\
\hline Error & 23 & 0.7261 & $\ldots$ & 0.6306 & $\ldots$ \\
\hline Corrected total & 47 & & & & \\
\hline Shapiro-Wilk test ${ }^{\mathrm{z}}$ & $\ldots$ & $P<\mathrm{W}$ & 0.6341 & $P<\mathrm{W}$ & 0.7185 \\
\hline
\end{tabular}

${ }^{y}$ Bunch sections bearing three to seven berries on a short rachis were left untreated, or were surfacesterilized. Both groups of sections were immersed in paraquat and incubated at $22^{\circ} \mathrm{C}$ under high humidity.

${ }^{\mathrm{z}}$ Test for non-normality.

Table 2. Analysis of variance of the incidence of Botrytis cinerea (logit transformed) recorded in the paraquat/freezing experiment at the base and cheek of Barlinka grape berries obtained during 199899 and 1999-2000 from vineyards at De Doorns and Paarl

\begin{tabular}{|c|c|c|c|c|c|}
\hline \multirow[b]{2}{*}{ Source } & \multirow[b]{2}{*}{ df } & \multicolumn{2}{|c|}{ Base } & \multicolumn{2}{|c|}{ Cheek } \\
\hline & & MS & $P>F$ & MS & $P>F$ \\
\hline Location & 1 & 28.99667 & 0.0003 & 15.45713 & 0.0041 \\
\hline Season (S) & 1 & 0.00084 & 0.9805 & 5.30536 & 0.0661 \\
\hline Growth stage $(\mathrm{G})$ & 3 & 5.20569 & 0.0331 & 4.59287 & 0.0455 \\
\hline $\mathrm{S} \times \mathrm{G}$ & 3 & 2.47762 & 0.1895 & 0.55481 & 0.7477 \\
\hline Treatment $(\mathrm{T})^{\mathrm{y}}$ & 1 & 1.89343 & 0.2585 & 1.06097 & 0.3895 \\
\hline $\mathrm{S} \times \mathrm{T}$ & 1 & 0.00004 & 0.9954 & 0.30064 & 0.6439 \\
\hline $\mathrm{G} \times \mathrm{T}$ & 3 & 1.91942 & 0.2820 & 1.37158 & 0.4134 \\
\hline $\mathrm{S} \times \mathrm{G} \times \mathrm{T}$ & 3 & 0.62562 & 0.7172 & 0.78767 & 0.6352 \\
\hline Error & 15 & 1.37276 & $\ldots$ & 1.35081 & $\ldots$ \\
\hline Corrected total & 31 & $\ldots$ & $\ldots$ & $\ldots$ & $\ldots$ \\
\hline Shapiro-Wilk test ${ }^{2}$ & $\ldots$ & $P<\mathrm{W}$ & 0.5836 & $P<\mathrm{W}$ & 0.9147 \\
\hline
\end{tabular}

$\mathrm{y}$ Two groups of bunch sections bearing three to seven berries on a short rachis were surfacesterilized. One group was immersed in paraquat and incubated at $22^{\circ} \mathrm{C}$ under high humidity. The other group was frozen for $1 \mathrm{~h}$ at $-12^{\circ} \mathrm{C}$ and kept in dry conditions ( $\leq 56 \%$ relative humidity) at $22^{\circ} \mathrm{C}$, followed by a 4-day incubation at high relative humidity to promote symptom expression.

${ }^{z}$ Test for non-normality.

Table 3. Mean incidence of Botrytis cinerea (logit transformed) recorded at four growth stages in the paraquat experiment at the base and cheek of Barlinka grape berries obtained during 1996-97, 199798, and 1998-99 from vineyards at De Doorns and Paarl ${ }^{\mathrm{z}}$

\begin{tabular}{lll}
\hline Growth stage & \multicolumn{1}{c}{ Base } & \multicolumn{1}{c}{ Cheek } \\
\hline Pea-size & $-2.0621 \mathrm{a}(11.30)$ & $-6.2511 \mathrm{~b}(0.19)$ \\
Bunch closure & $-1.5401 \mathrm{a}(17.60)$ & $-5.4556 \mathrm{a}(0.43)$ \\
Véraison & $-3.3467 \mathrm{~b}(3.40)$ & $-5.7272 \mathrm{ab}(0.32)$ \\
Harvest & $-4.4291 \mathrm{c}(1.20)$ & $-5.2260 \mathrm{a}(0.53)$ \\
\hline
\end{tabular}

${ }^{\mathrm{z}}$ Bunch sections bearing three to seven berries on a short rachis were left untreated or were surface sterilized. Both groups were immersed in paraquat and incubated at $22^{\circ} \mathrm{C}$ under high humidity. Means with the same letter do not differ significantly at the 5\% significance level according to Student's least significant difference test. Values in parenthesis are the means of the back transformed percentages.

the pathogen developed from this position in only $0.001 \%$ of the 44,930 berries on the 6,912 sections used in this study. Therefore, data of the stylar end was not included in the statistical analysis. Individual lesions seldom occurred on the cheek and the pathogen developed from a few berries initially from this position. On the majority of berries that yielded $B$. cinerea, symptom expression was first noticed at the base, irrespective of the sterilization regime. This was characterized by a browning of the skin at the base, which gradually extended to the central portion of the cheek, 3 to 5 days after the paraquat or freezing treatment. Sporulating colonies of the pathogen generally occurred after 7 to 9 days, first on the berry base, and later away from the base. On some of the berries that yielded the pathogen at the base, sporulation remained confined to this position. Levene's test for homogeneity of variance $(P>0.05)$ indicated that, for both the paraquat (Table 1) and the paraquat or freezing (Table 2) experiments, the seasonal variability in data of the base and cheek observations were of comparable magnitude and, hence, a combined analysis was validated. There was no evidence against normality $(P>0.58)$ in the logit transformed data; therefore, the analysis was considered valid. There was also no significant $(P>0.05)$ evidence for any second and higher order interactions. In the paraquat experiment, significantly more berries yielded the pathogen at the base and cheek positions under the unsterile than the sterile regime. At the base, surface sterilization caused a threefold reduction in the incidence of $B$. cinerea and reduced the mean incidence of symptomatic berries from 8.95 to $3.33 \%$. At the cheek, surface sterilization reduced the incidence of $B$. cinerea by twofold, but the mean incidence of symptomatic berries was extremely low for both treatments (untreated, $0.44 \%$ and surface sterilized, $0.27 \%$ ). Significantly more berries yielded the pathogen from the base at pea size and bunch closure stages than at véraison or harvest (Table 3). The opposite was found for the cheek position. At this position, the incidence was significantly lower at pea size stage than at harvest.

In the paraquat or freezing experiment, no significant difference was found between the mean incidence of $B$. cinerea for both berry positions. In the paraquat treatment, 3.0 and $0.29 \%$ of berries expressed symptoms at the base and cheek, respectively. In the freezing experiment, the mean incidence for the two positions was 1.87 and $0.42 \%$. The occurrence of the pathogen as latent mycelia significantly declined during the season at the base. Therefore, mycelia at this position resulted in $6.93 \%$ infected berries at pea size stage and $1.46 \%$ at the ripe stage (Table 4 ). For the cheek, the mean incidence of infected berries recorded at the different growth 
stages did not exceed $1 \%$. The pathogen, therefore, seldom occurred as latent mycelia at this position on berries.

Detection of $B$. cinerea and subsequent disease expression at different positions on leaves and bunches. In both seasons, symptoms were expressed in a consistent pattern on material of both cultivars. On material exposed to paraquat, browning of the tissue followed by the development of sporulating $B$. cinerea colonies first was noticeable on leaf blades approximately 3 to 4 days after treatment. The pathogen developed first alongside the veins and from the leaf basis. On some leaves, one to five separate lesions formed, or the pathogen developed scattered over the entire leaf blade. On the structural bunch parts, brown lesions appeared on the rachis, laterals, and pedicel after 4 to 7 days and sporulation occurred after 5 to 8 days. On berries, symptom expression was noticed first at the base. This was characterized 3 to 5 days after the paraquat treatment by a browning of the skin at the base, which gradually extended to the central portion of the berry. Sporulating colonies of the pathogen generally occurred after 5 to 7 days, first at the berry-pedicel attachment zone, and later on the discolored cheek. Individual lesions seldom occurred on the berry cheek, and the pathogen developed from a few berries initially from this position. On the untreated material, lesion development and sporulation by the pathogen were usually delayed. On leaves, lesions were few, mostly one per leaf blade and restricted. On some leaves, a lesion developed only at the leaf basis. On some of the berries that yielded the pathogen at the pedicle-berry attachment zone, sporulation remained confined to this position. For both treatments, the stylar end of the berries remained, at all samplings, mostly asymptomatic and virtually free from B. cinerea. Therefore, data of this position were not included in the analysis.

The ANOVA for the effect of season, cultivar, growth stage, position, and treatment showed that season, cultivar, growth stage, position, treatment, and their interaction had a highly significant effect $(P<0.01)$ on $B$. cinerea incidence (Table 5). Both cultivars showed some similarities in the pattern of $B$. cinerea occurrence between the two seasons. For clarity, the effects for the lower-order interaction cultivar-growth stage-position-treatment $(P=0.0003)$ are discussed (Table 6) using the mean values for the two seasons. Several general responses can be derived from the significant effect of the interaction. For both cultivars at each growth stage, the various positions displayed a significantly higher incidence of $B$. cinerea on tissues exposed to paraquat than on the untreated tissues. This was not the case for the berry cheek, which, for both cultivars, consistently yielded $B$. cinerea at a low incidence in both treatments. In bunches, based on the incidence of $B$. cinerea found in the paraquat treatment, the occurrence of the pathogen on rachises and laterals declined for both cultivars from pea-size to harvest stage. This decline also occurred at the pedicel and berry base of Dauphine, but not on those of Merlot. For the control treatment, the incidence of $B$. cinerea was mostly low at all of the positions for both cultivars. Exceptions were at pea-size stage for Dauphine, when the incidence of $B$. cinerea was significantly higher in rachises and laterals than at the other positions, and at harvest stage for Merlot, when the incidence was significantly higher at the pedicel and berry base.

The relationship between the incidence of $B$. cinerea recorded on tissues exposed to paraquat and the untreated tissues is given in Table 7. For the petiole and rachis for both cultivars there was no significant relationship. For the lateral, the correlation was significant $(r=0.6456, P=0.0438)$ for Merlot at pea-size stage. The incidence of $B$. cinerea tended to correlate negatively for the cheek, and the correlation was significant $(r=-0.6373, P=0.0475)$ for Merlot at pea-size stage. For Dauphine, the

Table 4. Mean incidence of Botrytis cinerea (logit transformed) recorded at four growth stages in the paraquat/freezing experiment at the base and cheek of Barlinka grape berries obtained during 199899 and 1999-2000 from vineyards at De Doorns and Paarl ${ }^{\mathrm{Z}}$

\begin{tabular}{lll}
\hline Growth stage & \multicolumn{1}{c}{ Base } & \multicolumn{1}{c}{ Cheek } \\
\hline Pea-size & $-2.5971 \mathrm{a}(6.93)$ & $-5.4658 \mathrm{ab}(0.42)$ \\
Bunch closure & $-3.6751 \mathrm{ab}(2.47)$ & $-6.1566 \mathrm{~b}(0.21)$ \\
Véraison & $-4.3896 \mathrm{~b}(1.23)$ & $-4.6462 \mathrm{a}(0.95)$ \\
Harvest & $-4.2108 \mathrm{~b}(1.46)$ & $-6.3014 \mathrm{~b}(0.18)$ \\
\hline
\end{tabular}

$\mathrm{z}$ Two groups of bunch sections bearing three to seven berries on a short rachis were surfacesterilized. One group was immersed in paraquat and incubated at $22^{\circ} \mathrm{C}$ under high humidity. The other group was frozen for $1 \mathrm{~h}$ at $-12^{\circ} \mathrm{C}$ and kept in dry conditions ( $\leq 56 \%$ relative humidity) at $22^{\circ} \mathrm{C}$, followed by a 4-day incubation at high relative humidity to promote symptom expression. Means with the same letter do not differ significantly at the $5 \%$ significance level according to Student's least significant difference test. Values in parenthesis are the means of the back transformed percentages.

Table 5. Analysis of variance for effects of season, growth stage, cultivar, treatment, and position on the incidence of Botrytis cinerea detected in leaves and bunches of grapevine

\begin{tabular}{|c|c|c|c|}
\hline Source of variation & df & MS & $P>F$ \\
\hline Season (S) & 1 & $23,914.671$ & 0.0001 \\
\hline Growth stage $(\mathrm{G})$ & 2 & $7,674.3$ & 0.0055 \\
\hline $\mathrm{S} \times \mathrm{G}$ & 2 & 751.043 & 0.537 \\
\hline Error $(S \times G)$ & 24 & $1,176.757$ & $\ldots$ \\
\hline Cultivar (C) & 1 & $4,452.805$ & 0.0273 \\
\hline $\mathrm{S} \times \mathrm{C}$ & 1 & 142.519 & 0.6779 \\
\hline $\mathrm{G} \times \mathrm{C}$ & 2 & $3,802.433$ & 0.0187 \\
\hline $\mathrm{S} \times \mathrm{G} \times \mathrm{C}$ & 2 & 721.633 & 0.4218 \\
\hline Error $(S \times G \times C)$ & 24 & 806.219 & $\ldots$ \\
\hline Treatment $(\mathrm{T})^{\mathrm{z}}$ & 1 & $174,932.005$ & 0.0001 \\
\hline $\mathrm{S} \times \mathrm{T}$ & 1 & $6,800.119$ & 0.0008 \\
\hline $\mathrm{G} \times \mathrm{T}$ & 2 & $11,716.176$ & 0.0001 \\
\hline $\mathrm{S} \times \mathrm{G} \times \mathrm{T}$ & 2 & $1,222.062$ & 0.1116 \\
\hline $\mathrm{C} \times \mathrm{T}$ & 1 & $3,432.386$ & 0.0144 \\
\hline $\mathrm{S} \times \mathrm{C} \times \mathrm{T}$ & 1 & 820.119 & 0.2205 \\
\hline $\mathrm{G} \times \mathrm{C} \times \mathrm{T}$ & 2 & 424.329 & 0.4564 \\
\hline $\mathrm{S} \times \mathrm{G} \times \mathrm{C} \times \mathrm{T}$ & 2 & 53.319 & 0.9048 \\
\hline Error $(\mathrm{S} \times \mathrm{G} \times \mathrm{C} \times \mathrm{T})$ & 48 & 532.117 & $\ldots$ \\
\hline Position (P) & 6 & $11,223.783$ & 0.0001 \\
\hline $\mathrm{S} \times \mathrm{P}$ & 6 & $1,182.894$ & 0.0001 \\
\hline $\mathrm{G} \times \mathrm{P}$ & 12 & $1,064.061$ & 0.0001 \\
\hline $\mathrm{S} \times \mathrm{G} \times \mathrm{P}$ & 12 & 306.449 & 0.0008 \\
\hline $\mathrm{C} \times \mathrm{P}$ & 6 & $1,461.071$ & 0.0001 \\
\hline $\mathrm{S} \times \mathrm{C} \times \mathrm{P}$ & 6 & 131.319 & 0.2902 \\
\hline $\mathrm{G} \times \mathrm{C} \times \mathrm{P}$ & 12 & 466.983 & 0.0001 \\
\hline $\mathrm{S} \times \mathrm{G} \times \mathrm{C} \times \mathrm{P}$ & 12 & 318.65 & 0.0005 \\
\hline $\mathrm{T} \times \mathrm{P}$ & 6 & $7,850.627$ & 0.0001 \\
\hline $\mathrm{S} \times \mathrm{T} \times \mathrm{P}$ & 6 & 858.525 & 0.0001 \\
\hline $\mathrm{G} \times \mathrm{T} \times \mathrm{P}$ & 12 & 1431.082 & 0.0001 \\
\hline $\mathrm{S} \times \mathrm{G} \times \mathrm{T} \times \mathrm{P}$ & 12 & 291.012 & 0.0014 \\
\hline $\mathrm{C} \times \mathrm{T} \times \mathrm{P}$ & 6 & 224.252 & 0.052 \\
\hline $\mathrm{S} \times \mathrm{C} \times \mathrm{T} \times \mathrm{P}$ & 6 & 86.875 & 0.5608 \\
\hline $\mathrm{G} \times \mathrm{C} \times \mathrm{T} \times \mathrm{P}$ & 12 & 329.979 & 0.0003 \\
\hline $\mathrm{S} \times \mathrm{G} \times \mathrm{C} \times \mathrm{T} \times \mathrm{P}$ & 12 & 345.925 & 0.0002 \\
\hline Error $(\mathrm{S} \times \mathrm{G} \times \mathrm{C} \times \mathrm{T} \times \mathrm{P})$ & 576 & 106.9829 & $\ldots$ \\
\hline
\end{tabular}

${ }^{\mathrm{z}}$ Leaves and bunch sections bearing three to seven berries on a short rachis were divided in two groups. One group was rinsed in sterile, deionized water, the other group was immersed in paraquat. Both groups were air dried and incubated at $22^{\circ} \mathrm{C}$ under high humidity. 
correlation was positive $(r=0.8091, P=$ $0.0046)$ at harvest. A different pattern was found at the bases of the pedicel and the berry. A strong positive linear relationship was found for Merlot at pea-size stage (pedicel, $r=0.8136, P=0.0041$ ), bunch closure (berry base, $r=0.8014, P=$ 0.0053 ), and harvest (pedicel, $r=0.9823$, $P<0.0001$; berry base, $r=0.9638, P<$ 0.0001).

\section{DISCUSSION}

The data on the occurrence of $B$. cinerea on grape material obtained from 1996 to 2000 from commercial vineyards planted with different cultivars give a new perspective to the ecology of the pathogen on grapevine and the development of gray mold in South Africa. The incidence at which $B$. cinerea was detected at various positions on leaves and in bunches normally differed between vineyards. These differences can be ascribed to the influence exerted in each vineyard on $B$. cinerea by different sets of environmental and climatic conditions and cultivation practices (33). For example, trellis systems used for wine grape vineyards differed from those used in table grape vineyards. Furthermore, weather conditions were more conducive for the development of $B$. cinerea during 1999 than 2000 (21). However, the various tests revealed that the pathogen generally occurred in a consistent pattern on leaves and in bunches from all vineyards. Based on the combined data for tissues that were exposed and unexposed to paraquat, $B$. cinerea occurred predominantly in bunches and was mostly associated with the bases of the berry and the pedicel. Overall, approximately $30 \%$ of the berries yielded $B$. cinerea at these positions. The next prominent positions occupied were leaf blades, rachises, and laterals, of which approximately $20 \%$ yielded B. cinerea. The pathogen occupied the petioles less often $(10 \%)$ and the berry cheek infrequently $(5 \%)$. The stylar end of the berries, on the other hand, was virtually free $(0.02 \%)$ of the pathogen. Furthermore, the data of the paraquat treatment, which displayed the total inoculum at the various positions, showed that the incidence of $B$. cinerea was higher in bunches during the early part of the season than later in the season. This suggests that, in the Western Cape province, inoculum is dispersed more regularly in bunches from bloom to bunch closure than from véraison to harvest.
The tests showed that disease expression in bunches displayed the pattern showed by the inoculum ecology, and that disease expression consistently developed first at the berry-pedicel attachment zone. By using a differential set of paraquat and freezing treatments on untreated and surface-sterilized berries, it was found that, at all phenological stages, the stylar end was virtually free of $B$. cinerea. The isolation studies showed that the pathogen seldom occurred on the surface or in the skin tissue near the base, cheek, or stylar end of the berry. Collectively, these findings indicate that gray mold in these vineyards was unlikely to be caused by colonization of the pistil and subsequent latency in the stylar end, as was observed elsewhere $(41,47)$. It also was unlikely for berry rot to be caused by the very low amounts of $B$. cinerea occurring on the skin surface or in the skin tissue, as was suggested by Holz and coworkers (10-12,22,26-29). Instead, berry rot developed primarily from the berry-pedicel attachment zone. The differential set of paraquat and freezing treatments on surface-sterilized and untreated bunch sections showed that latent infections in the berry base were few at véraison and harvest. Observations made in other

Table 6. Means of the effect for the interaction cultivar-growth stage (GS)-position-treatment (T) on Botrytis cinerea incidence recorded in leaves and bunches of Dauphine (Daup) and Merlot (Merl) grapes ${ }^{\mathrm{x}}$

\begin{tabular}{|c|c|c|c|c|c|c|c|c|c|c|c|c|c|c|}
\hline \multirow[b]{3}{*}{ GS, T } & \multicolumn{4}{|c|}{ Leaf } & \multicolumn{6}{|c|}{ Bunch $^{y}$} & \multicolumn{4}{|c|}{ Berry $^{z}$} \\
\hline & \multicolumn{2}{|c|}{ Blade } & \multicolumn{2}{|c|}{ Petiole } & \multicolumn{2}{|c|}{ Rachis } & \multicolumn{2}{|c|}{ Lateral } & \multicolumn{2}{|c|}{ Pedicel } & \multicolumn{2}{|c|}{ Base } & \multicolumn{2}{|c|}{ Cheek } \\
\hline & Daup & Merl & Daup & Merl & Daup & Merl & Daup & Merl & Daup & Merl & Daup & Merl & Daup & Merl \\
\hline \multicolumn{15}{|l|}{ Pea-size } \\
\hline Control & $3.2 \mathrm{jk}$ & $2.4 \mathrm{jk}$ & $4.6 \mathrm{ijk}$ & $1.6 \mathrm{jk}$ & $13.6 \mathrm{fgh}$ & $0.4 \mathrm{k}$ & 13.2 fghi & $1.8 \mathrm{jk}$ & 8.2 ghijk & $2.4 \mathrm{jk}$ & $1.6 \mathrm{jk}$ & $0.2 \mathrm{k}$ & $5.2 \mathrm{hijk}$ & $4.4 \mathrm{jk}$ \\
\hline Paraquat & $38.2 \mathrm{e}$ & $33.2 \mathrm{e}$ & $20.2 \mathrm{f}$ & $16.8 \mathrm{gf}$ & $48.6 \mathrm{~d}$ & $60.6 \mathrm{c}$ & $50.0 \mathrm{~d}$ & $62.8 \mathrm{c}$ & $49.0 \mathrm{~d}$ & $68.2 \mathrm{ab}$ & $75.2 \mathrm{ab}$ & $82.0 \mathrm{a}$ & $9.2 \mathrm{ghij}$ & $6.6 \mathrm{hijk}$ \\
\hline \multicolumn{15}{|l|}{$\begin{array}{l}\text { Bunch } \\
\text { closure }\end{array}$} \\
\hline Control & $7.6 \mathrm{j}$ & $1.2 \mathrm{j}$ & $6.2 \mathrm{j}$ & $2.0 \mathrm{j}$ & $0.8 \mathrm{j}$ & $1.8 \mathrm{j}$ & $1.2 \mathrm{j}$ & $4.8 \mathrm{j}$ & $5.4 \mathrm{j}$ & $8.8 \mathrm{ij}$ & $3.4 \mathrm{j}$ & $2.2 \mathrm{j}$ & $5.0 \mathrm{j}$ & $3.6 \mathrm{j}$ \\
\hline Paraquat & $53.2 \mathrm{bc}$ & $39.4 \mathrm{ef}$ & $23.8 \mathrm{gh}$ & $18.8 \mathrm{ih}$ & $28.0 \mathrm{gh}$ & $31.6 \mathrm{gf}$ & $42.2 \mathrm{ed}$ & $39.4 \mathrm{ef}$ & $50.4 \mathrm{bcd}$ & $65.8 \mathrm{a}$ & $45.4 \mathrm{cde}$ & $58.6 \mathrm{ab}$ & $3.2 \mathrm{j}$ & $4.2 \mathrm{j}$ \\
\hline \multicolumn{15}{|l|}{ Harvest } \\
\hline Control & $1.2 \mathrm{~g}$ & $0.4 \mathrm{~g}$ & $1.0 \mathrm{~g}$ & $0.2 \mathrm{~g}$ & $3.0 \mathrm{~g}$ & $3.8 \mathrm{gh}$ & $2.4 \mathrm{~g}$ & $4.6 \mathrm{gh}$ & $5.6 \mathrm{gh}$ & $26.8 \mathrm{~cd}$ & $4.2 \mathrm{gh}$ & $31.8 \mathrm{c}$ & $2.6 \mathrm{~g}$ & $5.8 \mathrm{gh}$ \\
\hline Paraquat & $20.4 \mathrm{ed}$ & $46.0 \mathrm{~b}$ & $3.8 \mathrm{gh}$ & $19.0 \mathrm{def}$ & $15.6 \mathrm{ef}$ & $15.8 \mathrm{ef}$ & $11.8 \mathrm{gf}$ & $18.6 \mathrm{def}$ & $18.6 \mathrm{def}$ & $52.0 \mathrm{ab}$ & $11.6 \mathrm{gf}$ & $57.0 \mathrm{a}$ & $2.0 \mathrm{~g}$ & $5.6 \mathrm{gh}$ \\
\hline
\end{tabular}

${ }^{x}$ Average values of data recorded over two seasons in material from five Dauphine (table grape), and five Merlot (wine grape) vineyards. Values in each growth stage followed by the same letter are not significantly different according to the Student's $t$ test at $P=0.05$.

${ }^{\mathrm{y}}$ Bunch $=$ position on structural parts of the bunch.

${ }^{\mathrm{z}}$ Berry $=$ position on berries.

Table 7. Correlation coefficients between Botrytis cinerea incidence data recorded at different growth stages (GS) at various positions in leaves and bunches of Dauphine and Merlot grapes that were treated and not treated with paraquat ${ }^{\mathrm{x}}$

\begin{tabular}{|c|c|c|c|c|c|c|c|}
\hline \multirow[b]{2}{*}{ GS, cultivar } & \multicolumn{2}{|c|}{ Leaf } & \multicolumn{3}{|c|}{ Bunch $^{y}$} & \multicolumn{2}{|c|}{ Berry $^{z}$} \\
\hline & Blade & Petiole & Rachis & Lateral & Pedicel & Base & Cheek \\
\hline \multicolumn{8}{|l|}{ Pea-size } \\
\hline Dauphine & $0.5489(0.0757)$ & $0.0900(0.8046)$ & $0.4421(0.2007)$ & $0.4692(0.1712)$ & $-0.0562(0.8774)$ & $-0.2604(0.4674)$ & $-0.5127(0.1219)$ \\
\hline Merlot & $0.4413(0.2016)$ & $0.5733(0.0832)$ & $0.4576(0.1836)$ & $0.6456(0.0438 *)$ & $0.8136(0.0042 *)$ & $0.2195(0.5423)$ & $-0.6373\left(0.0475^{*}\right)$ \\
\hline \multicolumn{8}{|l|}{ Bunch closure } \\
\hline Dauphine & $0.1630(0.6527)$ & $0.2420(0.5005)$ & $0.5937(0.0703)$ & $0.5881(0.0737)$ & $0.5321(0.1134)$ & $0.3410(0.3349)$ & $-0.0122(0.9732)$ \\
\hline Merlot & $0.2786(0.4357)$ & $0.4778(0.1624)$ & $0.3688(0.2943)$ & $0.1146(0.7524)$ & $0.4808(0.1595)$ & $0.8014(0.0053 *)$ & $0.5538(0.0967)$ \\
\hline \multicolumn{8}{|l|}{ Harvest } \\
\hline Dauphine & $0.4453(0.1971)$ & $-0.5576(0.0940)$ & $0.1427(0.6941)$ & $-0.1104(0.7611)$ & $0.3922(0.2622)$ & $0.5313(0.1140)$ & $0.8091(0.0046 *)$ \\
\hline Merlot & $0.6913\left(0.0268^{*}\right)$ & $0.1238(0.7331)$ & $0.3294(0.3527)$ & $0.5244(0.1196)$ & $0.9832\left(<0.0001^{*}\right)$ & $0.9638(<0.0001 *)$ & $-0.1775(0.6236)$ \\
\hline
\end{tabular}

$\overline{\mathrm{x}}$ Total of experiments carried out between 1999 and 2000 with material from five Dauphine (table grape) and five Merlot (wine grape) vineyards. Values are correlation coefficients and corresponding $P$ values (in parentheses); * significant at $P=0.05$.

${ }^{\mathrm{y}}$ Bunch $=$ position on structural bunch parts.

${ }^{\mathrm{z}}$ Berry $=$ position on berries. 
studies confirmed this trend of natural $B$. cinerea occurrence on the table grape cv. Waltham Cross $(26,29)$ and wine grape cvs. Chardonnay, Chenin Blanc, and Shiraz (29). These findings indicate that conidia dispersed in the early season in bunches, and residing superficially at the berrypedicel attachment zone, are a major factor in $B$. cinerea bunch rot. The $B$. cinerea occupation pattern explains why gray mold develops mostly from the inner bunch $(43,45,47)$ and why disease management strategies should concentrate on the prebunch closure stage and on inhibiting $B$. cinerea development in the inner bunch during the early part of the season.

Working with mature Thompson Seedless, Marois et al. (40) demonstrated that the berry-to-berry contact areas on fresh and stored grapes are more susceptible to $B$. cinerea due to reduced deposition of cuticle and epicuticular wax. Nair et al. (44) studied factors that predispose grape berries to infection by the pathogen and concluded that infection cannot take place through uninjured skin. Our findings on the reaction of grape berry cheeks to $B$. cinerea substantiated the latter finding, and confirmed those of Holz and coworkers (10-12,26-29) on the resistance of grape skins to $B$. cinerea infection and to disease expression by airborne conidia. The finding that the amount of $B$. cinerea was consistently low on grape skins is also in accordance with the hypothesis that $B$. cinerea conidia are deposited as single cells on berry surfaces $(10-12,22,26,29)$ and that single conidia of the pathogen do not survive for extended periods on berry surfaces $(11,12,21)$. In most studies where grapes were artificially inoculated, mature berries were atomized with $(15,43,44,48)$, dipped in (6), or injected with $(2,39,65)$ conidial suspensions, or suspension droplets were placed onto the berry cheek $(9,38,40)$. These methods allowed for the deposition of clusters of conidia, and may differ from primary natural inoculation in the vineyard, where single conidia may be deposited simultaneously at several sites on the berry surface.

The phenomenon that grape leaf blades carry high amounts of $B$. cinerea suggests that leaf infection is an important primary infection event and plays an important role in the epidemiology of the pathogen on grape. The role of latent $B$. cinerea mycelia in leaves in the epidemiology of gray mold on perennial strawberries is well established. Young leaves are highly susceptible to infection, which becomes latent. As the leaves senesce and die, the fungus colonizes the tissues and sporulates $(4,5)$. Conidia formed on dying and necrotic leaves are the principal source of inoculum for $B$. cinerea fruit rot epidemics. In grapevine, sclerotia are a source of conidia that result in primary infection of young tissue (46). Thomas et al. (64) showed that the bulk of sclerotia recovered from vineyard soils in the Western Cape province developed on vine leaves and shredded prunings. Therefore, primary leaf infection that become latent is likely prior to bloom when daily air temperature during spring reaches $20^{\circ} \mathrm{C}$ (46). Although these infections mostly remain asymptomatic (21), spots may develop on young leaves removed prebloom during canopy management from vines, and the leaf-infection sites can produce conidia abundantly during wet periods $(21,45,64)$, thereby contributing to the inoculum load dispersed in bunches from bloom to bunch closure.

$B$. cinerea studies on timing of fungicide application, biological control, host resistance, and disease prediction models usually comprise investigations on mature berries $(2,6,9,15,38-40,44,66)$. The rationale for this is that the most prominent phase of the disease is found on berries $(41,43,45,47)$. Our investigations on the ecology of the pathogen at different positions in bunches, and on the relationship between the occurrence of $B$. cinerea and subsequent disease expression, suggest that more emphasis should be placed on the behavior of the pathogen on structures of the inner bunch. For these structures, no clear relationship was found between the incidence of $B$. cinerea occupation and subsequent symptom expression at pea-size and bunch closure. Disease expression only developed when host resistance was terminated by applying paraquat or freezing as stress factors. The two cultivars also may differ in resistance of their bunch parts to natural $B$. cinerea infection. For Merlot, a strong positive linear relationship between $B$. cinerea incidence data of paraquat-treated and untreated material was found at harvest for both the pedicel and the berry base. On Dauphine, the incidence of $B$. cinerea declined at the berry base and on the pedicel but, on Merlot, the incidence remained high throughout the season at these positions. Therefore, $B$. cinerea conidia and germlings may have different survival periods on tissues of the various positions, as is implicated by the low incidence at which the pathogen was detected at the cheek and the high incidence of occurrence on the rachis, lateral, and pedicel. In this context, it was shown previously that single conidia of the pathogen did not survive for extended periods on berry surfaces (10-12,21). Passive defense (proanthocyanidins [25] or substances in exudates $[12,36,41,51,53,68])$ and active defense (lignification-like reactions [30], phytoalexins [12,37], and suberin [12,24]) mechanisms may play a differential role in the resistance of the different tissues to infection by $B$. cinerea and in the survival of conidia, germlings, and latent mycelia of the pathogen.

Throughout this study, and in other studies (27-29) where bunches were subjected to paraquat and freezing treatment, it was noted (data not included) that other fungi (Penicillium, Aspergillus, Alternaria, Mucor, and Rhizopus spp.) commonly associated with bunch rot (23) developed in pattern similar to that of $B$. cinerea at the various positions in bunches. It was previously shown that Alternaria alternata penetrated rachises and pedicels through stomata and lenticels, and causes rot of cold-stored table grapes when they were subjected to stress conditions $(62,63)$. From this, it can be concluded that the importance of these fungi residing at the berry-pedicel attachment zone is underestimated in their epidemiology and the development of bunch rot epiphytotics in grapevine. Stress factors operative on vines, for example those that cause rupture at the berry base $(33,66)$, should play an important role in disease expression by the different fungi in the vineyard.

\section{ACKNOWLEDGMENTS}

We thank E. J. Havinga and M. E. Isaacks for technical assistance.

\section{LITERATURE CITED}

1. Agulhon, R., Built, J., Lafon, J., Roussel, C., Pourcharesse, P., and Burgaud, L. 1971. La pourriture grise des raisins. Vigne Vin. 196:17-24.

2. Avissar, I., and Pesis, E. 1991. The control of postharvest decay in table grapes using acetaldehyde vapours. Ann. Appl. Biol. 118:229237.

3. Baur, J. R., Bovey, R. W., Baur, P. S., and ElSeify, Z. 1969. Effects of paraquat on the ultrastructure of mesquite mesophyll cells. Weed Res. 9:81-85.

4. Braun, P. G., and Sutton, J. C. 1987. Inoculum sources of $B$. cinerea in fruit rot of strawberry in Ontario. Can. J. Plant Pathol. 9:1-5.

5. Braun, P. G., and Sutton, J. C. 1988. Infection cycles and population dynamics of Botrytis cinerea in strawberry leaves. Can. J. Plant Pathol. 10:133-141.

6. Broome, J. C., English, J. T., Marois, J. J., Latorre, B. A., and Aviles, J. C. 1995. Development of an infection model for Botrytis bunch rot of grapes based on wetness duration and temperature. Phytopathology 85:97-102.

7. Bulit, J., and Verdu, D. 1973. Annual Variations in the Aerial Sporing of Botrytis cinerea in a Vineyard. Proc. Eur. Botrytis Symp. 28 June-1 July, Teresin, Poland.

8. Cerkauskas, R. F., and Sinclair, J. B. 1980 Use of paraquat to aid detection of fungi in soybean tissues. Phytopathology 70:10361038.

9. Chardonnet, C., L'Hyvernay, A., and Doneche, B. 1997. Effect of calcium treatment prior to Botrytis cinerea infection on the changes in pectic composition of grape berry. Physiol. Mol. Plant Pathol. 50:213-218.

10. Coertze, S., and Holz, G. 1999. Surface colonization, penetration, and lesion formation on grapes inoculated fresh or after cold storage with single airborne conidia of Botrytis cinerea. Plant Dis. 83:917-924.

11. Coertze, S., and Holz, G. Epidemiology of Botrytis cinerea on grape: wound infection by dry, airborne conidia. S. Afr. J. Enol. Vitic. 23:72-77.

12. Coertze, S., Holz, G., and Sadie, A. 2001. Germination and establishment of infection on grape berries by single airborne conidia of Botrytis cinerea. Plant Dis. 85:668-677.

13. Corbaz, R. 1972. Etudes des spores fongiques captées dans 1'air. Phytopathol. Z. 74:318328. 
14. De Klerk, C. A. 1985. Chemical control programme for vine diseases and pests. In: Farming in South Africa. Viticultural and Oenological Series 200. Nietvoorbij Institute for Viticulture and Oenology, Stellenbosch, South Africa.

15. De Kock, P. J., and Holz, G. 1991. Colonization of table grapes by Botrytis cinerea in the Western Cape province. Phytophylactica 23:73-80.

16. Doss, R. P., Potter, S. W., Chastagner, G. A., and Christain, J. K. 1993. Adhesion of nongerminated Botrytis cinerea conidia to several substrata. Appl. Environ. Microbiol. 59:1786-1791.

17. Doss, R. P., Potter, S. W., Soeldner, A. H., Christain, J. K., and Fukunaga, L. E. 1995. Adhesion of germlings of Botrytis cinerea. Appl. Environ. Microbiol. 61:206-265.

18. Duncan, R. A., Stapleton, J. J., and Leavitt, G. M. 1995. Population dynamics of epiphytic mycoflora and occurrence of bunch rots of wine grapes as influenced by leaf removal. Plant Pathol. 44:956-965.

19. Gessler, A., and Jermini, M. 1985. Role of flower infections of grape by Botrytis cinerea and consequences for the spraying schedule. Quad. Vitic. Enol. Univ. Torino 9:245-250.

20. Grindrat, D., and Pezet, R. 1994. Le paraquat, un outil pour la révélation rapide d'infections fongiques latentes et de champignons endophytes. J. Phytopathol. 141:86-89.

21. Gütschow, M. 2001. Resistance to Botrytis cinerea in parts of leaves and bunches of grapevine. M.Sc. Agric. thesis, University of Stellenbosch, Stellenbosch, South Africa.

22. Gütschow, M., and Holz, G. 2000. Resistance to Botrytis cinerea in morphological parts of a selected table and wine grape cultivar. Page P46 in: (Abstr.). XIIth Int. Botrytis Symp. Reims, France.

23. Hewitt, W. B. 1974. Rots and bunch rots of grapes. Calif. Agric. Exp. Stn. Bull. 868.

24. Hill, G. K. 1985. Suberization of cell walls: A defence reaction of grape stem tissue against invading mycelium of Botrytis cinerea. Quad. Vitic. Enol. Univ. Torino 9:229-230.

25. Hill, G. K., Stellwaag-Kittler, F., Huth, G., and Schlösser, E. 1981. Resistance of grapes in different developmental stages to Botrytis cinerea. Phytopathol. Z. 102:328-338.

26. Holz, G. 1999. Behaviour and infection pathways of diverse fungal pathogens on fruit. Page 257 in: (Abstr.) Conf. Handb. 12th Bien. Aust. Plant Pathol. Soc. Conf. Canberra, Australia.

27. Holz, G., Coertze, S., and Basson, E. J. 1997. Latent infection of Botrytis cinerea in grape pedicels leads to postharvest decay. (Abstr.). Phytopathology 87:S43.

28. Holz, G., Coertze, S., and Basson, E. J. 1998. Infection pathways and latency of Botrytis cinerea in grape bunches. (Abstr.). 7th Int. Congr. Plant Pathol. Edinburgh, Scotland, Vol. 3:6.22.

29. Holz, G., Gütschow, M., Frederiks, C., du Preez, I. F., and Coertze, S. 2000. Infection pathways of Botrytis cinerea on grape bunches. Page L23 in: (Abstr.). XIIth Int. Botrytis Symp. Reims, France.

30. Hoos, G., and Blaich, R. 1988. Metabolism of stilbene phytoalexins in grapevines: oxidation of resveratrol in single-cell cultures. Vitis 27:1-12.

31. Jarvis, W. R. 1962. The dispersal of spores of Botrytis cinerea Fr. in a raspberry plantation. Trans. Br. Mycol. Soc. 45:549-559.

32. Jarvis, W. R. 1962. Splash dispersal of spores of Botrytis cinerea Pers. Nature (Lond.) 193:599.

33. Jarvis, W. R. 1980. Epidemiology. Pages 219-
250 in: The Biology of Botrytis. J. R. ColeySmith, K. Verhoeff, and W. R. Jarvis, eds. Academic Press, New York.

34. Jermini, M., Jelmini, G., and Gessler, C. 1986. La lutte contre le Botrytis cinerea du Merlot au Tessin. Le rôle des infections latentes. Rev. Suisse Vitic. Arboric. Hortic. 18:161-166.

35. Kerssies, A. 1990. A selective medium for Botrytis cinerea to be used in a spore-trap. Neth. J. Plant Pathol. 96:247-250.

36. Kosuge, T., and Hewitt, W. B. 1964. Exudates of grape berries and their effect on germination of conidia of Botrytis cinerea. Phytopathology 54:167-17.

37. Langcake, P. 1981. Disease resistance of Vitis spp. and the production of the stress metabolites resveratrol, $\varepsilon$-viniferin, $\alpha$-viniferin and pterostilbene. Physiol. Plant Pathol. 18:213226.

38. Marois, J. J., Bledsoe, A. M., Bostock, R. M., and Gubler, W. D. 1987. Effects of spray adjuvants on development of Botrytis cinerea on Vitis vinifera berries. Phytopathology 77: 1148-1152.

39. Marois, J. J., Bledsoe, A. M., Gubler, W. D., and Luvisi, D. A. 1986. Control of Botrytis cinerea on grape berries during postharvest storage with reduced levels of sulfur dioxide. Plant Dis. 70:1050-1052.

40. Marois, J. J., Nelson, J. K., Morrison, J. C., Lile, L. S., and Bledsoe, A. M. 1986. The influence of berry contact within grape clusters on the development of Botrytis cinerea and epicuticular wax. Am. J. Enol. Vitic. 37:293-296.

41. McClellan, W. D., and Hewitt, B. 1973. Early Botrytis rot of grapes: Time of infection and latency of Botrytis cinerea Pers. in Vitis vinifera L. Phytopathology 63:1151-1157.

42. Michailides, T. J., Morgan, D. P., Felts, D., and Peacock, B. 2000. Infection of California table grapes and detection and significance of symptomless latent infection by Botrytis cinerea. Page P48 in: (Abstr.). XIIth Int. Botrytis Symp. Reims, France.

43. Nair, N. G. 1985. Fungi associated with bunch rot of grapes in the Hunter Valley. Aust. J. Agric. Res. 36:435-442.

44. Nair, N. G., Emmett, R. W., and Parker, F. E. 1988. Some factors predisposing grape berries to infection by Botrytis cinerea. N. Z. J. Exp. Agric. 16:257-263.

45. Nair, N. G., and Hill, G. K. 1992. Bunch rot of grapes caused by Botrytis cinerea. Pages 147-169 in: Plant Diseases of International Importance. Vol III: Diseases of Fruit Crops. J. Kumar, H. S. Chaube, U. S. Singh, and A. N. Mukhopadhyoy, eds. Prentice-Hall, Englewood Cliffs, NJ.

46. Nair, N. G, and Nadtotchei, A. 1987. Sclerotia of Botrytis as a source of primary inoculum for bunch rot of grapes in New South Wales, Australia. J. Phytopathol. 119:42-51.

47. Nair, N. G., and Parker, F. E. 1985. Midseason bunch rot of grapes: an unusual disease phenomenon in the Hunter Valley, Australia. Plant Pathol. 34:302-305

48. Nelson, K. E. 1951. Effect of humidity on infection of table grapes by Botrytis cinerea. Phytopathology 41:859-864.

49. Nelson, K. E. 1956. The effect of Botrytis infection on the tissue of Tokay grapes. Phytopathology 46:223-229.

50. Northover, J. 1987. Infection sites and fungicidal prevention of Botrytis cinerea bunch rot of grapes in Ontario. Can. J. Plant Pathol. 9:129-136.

51. Padgett, M., and Morrison, J. C. 1990. Changes in the grape berry exudates during fruit development and their effect on the mycelial growth of Botrytis cinerea. J. Am. Soc. Hortic. Sci. 115:269-273.

52. Pearson, R. C., and Riegel, D. G. 1983. Control of Botrytis bunch rot of ripening grapes: timing application of the dicarboximide fungicides. Am. J. Enol. Vitic. 34:167-172.

53. Pezet, R., and Pont, V. 1984. Botrytis cinerea Activité antifongique dans les jeunes grappes de Vitis vinifera, Varieté Gamay. Phytopathol. Z. 111:73-81

54. Pezet, R., and Pont, V. 1986. Infection florale et latence de Botrytis cinerea dans les grappes de Vitis vinifera (var. Gamay). Rev. Suisse Vitic. Arboric. Hortic. 18:317-322.

55. Pscheidt, J. W., and Pearson, R. C. 1989. Time of infection and control of Phomopsis fruit rot of grape. Plant Dis. 73:829-833.

56. Pucheu-Planté, B., and Mercier, M. 1983. Étude ultrastructurale de l'interrelation hôteparasite entre le raisin et le champignon Botrytis cinerea: exemple de la pourriture noble en Sauternais. Can. J. Bot. 61:1785-1797.

57. Savage, S. D., and Sall, M. A. 1982. The use of a radio-immunosorbent assay for Botrytis cinerea. EPPO Bull. 12:49-53.

58. Shapiro, S. S., and Wilk, M. B. 1965. An analysis of variance (complete samples). Biometrika 52:591-611.

59. Snedecor, G. W., and Cochran, W. G. 1980. Statistical Methods. 7th ed. Iowa State University Press, Ames.

60. Sparapano, L., Ferrara, G., Frisullo, S., and Ciccarone, A. 1981. Preliminary observations on the oversummering of Botrytis cinerea Per. ex Fr. in grapevine berries, in Apulia. Phytopathol. Mediterr. 20:152-163.

61. Spotts, R. A., and Holz, G. 1996. Adhesion and removal of conidia of Botrytis cinerea and Penicillium expansum from grape and plum fruit surfaces. Plant Dis. 80:688-691.

62. Swart, A. E., and Holz, G. 1994. Colonization of table grape bunches by Alternaria alternata and rot of cold-stored grapes. S. Afr J. Enol. Vitic. 15:19-25.

63. Swart, A. E., Lennox, C. L., and Holz, G. 1995. Infection of table grape bunches by $A l$ ternaria alternata. S. Afr. J. Enol. Vitic. 16:3-

64. Thomas, A. C., Matthee, F. N., and Kotze, J. M. 1981. Survival of Botrytis cinerea from table grapevines in South Africa. Phytophylactica 13:157-160.

65. Thomas, C. S., Marois, J. J., and English, J. T. 1988. The effects of wind speed, temperature and relative humidity on development of aerial mycelium and conidia of Botrytis cinerea on grape. Phytopathology 78:260-265.

66. Vail, M. E., and Marois, J. J. 1991. Grape cluster architecture and the susceptibility of berries to Botrytis cinerea. Phytopathology 81:188-191.

67. Van der Merwe, G. G., Geldenhuys, P. D., and Botes, W. S., 1991. Guidelines for the Preparation of Table Grape Cultivars for Export. Unifruco, Bellville, South Africa.

68. Vercesi, A., Locci, R., and Prosser, J. I. 1997. Growth kinetics of Botrytis cinerea on organic acids and sugars in relation to colonization of grape berries. Mycol. Res. 101:139-142.

69. Warren, M. A., Becker, N., Mebalds, M., and Glenn, D. C. 1999. The link between spore concentration, flower infection and subsequent bunch rot caused by Botrytis cinerea in winegrapes. Page 293 in: Conf. Handb. 12th Bien. Aust. Plant Pathol. Soc. Conf. Canberra, Australia.

70. Wolf, T. K., Baudoin, A. B. A. M., and Martinez-Ochoa, N. 1997. Effect of floral debris removal from fruit clusters on botrytis bunch rot of Chardonnay grapes. Vitis 36:27-33. 